\title{
Resynchronization of ovulation protocols for dairy cows including or not including gonadotropin-releasing hormone to induce a new follicular wave: Effects on re-insemination pattern, ovarian responses, and pregnancy outcomes
}

\author{
R. Wijma, M. L. Stangaferro, M. Masello, G. E. Granados, and J. O. Giordano ${ }^{1}$ \\ Department of Animal Science, Cornell University, Ithaca 14853
}

\section{ABSTRACT}

Our objectives were to evaluate the pattern of reinsemination, ovarian responses, and pregnancy per artificial insemination $(\mathrm{P} / \mathrm{AI})$ of cows submitted to different resynchronization of ovulation protocols. The base protocol started at $25 \pm 3 \mathrm{~d}$ after artificial insemination (AI) and was as follows: GnRH, 7 and $8 \mathrm{~d}$ later $\mathrm{PGF}_{2 \alpha}$, GnRH $32 \mathrm{~h}$ after second $\mathrm{PGF}_{2 \alpha}$, and fixed timed AI (TAI) 16 to $18 \mathrm{~h}$ after GnRH. At $18 \pm 3 \mathrm{~d}$ after AI, cows were randomly assigned to the G25 ( $\mathrm{n}=$ $1,100)$ or NoG25 $(\mathrm{n}=1,098)$ treatments. The protocol for G25 and NoG25 was the same, except that cows in NoG25 did not receive GnRH $25 \pm 3$ d after AI. At nonpregnancy diagnosis (NPD), $32 \pm 3 \mathrm{~d}$ after AI, cows from G25 and NoG25 with a corpus luteum (CL) $\geq 15$ $\mathrm{mm}$ in diameter and a follicle $\geq 10 \mathrm{~mm}$ completed the protocol $(\mathrm{G} 25 \mathrm{CL}=272$, NoG25 CL $=194)$, whereas cows from both treatments that did not meet these criteria received a modified Ovsynch protocol with $\mathrm{P} 4$ supplementation [controlled internal drug release insert plus $\mathrm{GnRH}$, controlled internal drug release insert removal, and $\mathrm{PGF}_{2 \alpha} 7$ and $8 \mathrm{~d}$ later, GnRH $32 \mathrm{~h}$ after second $\mathrm{PGF}_{2 \alpha}$, and TAI 16 to $18 \mathrm{~h}$ after GnRH (G25 NoCL $=53$, NoG25 NoCL $=78)]$. Serum concentrations of progesterone $(\mathrm{P} 4)$ were determined and ovarian ultrasonography was performed thrice weekly from 18 $\pm 3 \mathrm{~d}$ after AI until $1 \mathrm{~d}$ after TAI (G25 = 46, NoG25 = 44 cows). A greater percentage of NoG25 cows were reinseminated at detected estrus (NoG25 $=53.5 \%, \mathrm{G} 25$ $=44.6 \%$ ), whereas more cows had a CL at NPD in G25 than NoG25 (83.7 and 71.3\%). At $32 \mathrm{~d}$ after AI, P/AI was similar for G25 and NoG25 for inseminations at detected estrus (38.4 and 42.9\%), TAI services for cows with no CL (40.4 and 36.7\%), and for all services com-

Received January 3, 2017.

Accepted May 9, 2017

${ }^{1}$ Corresponding author: jog25@cornell.edu bined (39.6 and 39.0\%). However, P/AI were greater for cows with a CL in G25 than NoG25 (40.6 and 32.8\%) that received TAI. More cows ovulated spontaneously or in response to GnRH for the G25 than the NoG25 treatment (70 and $36 \%$ ) but a similar proportion had an active follicle at NPD (G25 = 91\% and NoG25 = $96 \%)$. The largest follicle diameter at NPD (G25 $=15.0$ $\pm 0.4 \mathrm{~mm}$, NoG25 $=16.5 \pm 0.6 \mathrm{~mm}$ ) and days since it reached $\geq 10 \mathrm{~mm}(\mathrm{G} 25=4.0 \pm 0.3 \mathrm{~d}$, NoG25 $=5.8 \pm$ $0.6 \mathrm{~d}$ ) were greater for the NoG25 than G25 treatment. For cows with a CL at NPD, CL regression after NPD, ovulation after TAI, and ovulatory follicle diameter did not differ. In conclusion, removing the first $\mathrm{GnRH}$ of a modified Resynch-25 protocol for cows with a CL at NPD and a modified Ovsynch protocol with P4 supplementation for cows without a CL at NPD resulted in a greater percentage of cows re-inseminated at detected estrus and a similar proportion of cows pregnant in spite of reduced P/AI for cows with a CL at NPD.

Key words: resynchronization, estrus detection, gonadotropin-releasing hormone, dairy cow

\section{INTRODUCTION}

An ideal strategy for submitting cows for re-insemination minimizes the interbreeding interval and maximizes pregnancy per AI (P/AI). Many dairy farms reduce the interbreeding interval by combining re-insemination of cows after a detected estrus and submission to resynchronization of ovulation for timed AI (TAI; Caraviello et al., 2006; Ferguson and Skidmore, 2013; Scott, 2016). Re-insemination of cows at estrus with resulting $\mathrm{P} / \mathrm{AI}$ similar to or better than that observed after re-insemination at fixed time AI benefits herd profitability by reducing the overall interbreeding interval and reproductive program cost (Giordano et al., 2012b, 2013; Galvão et al., 2013). On the other hand, incorporating a resynchronization of ovulation protocol for TAI is essential because it ensures timely re-insemination of nonpregnant cows not detected in 
estrus. Therefore, Ovsynch-type protocols are usually initiated at the time of or $7 \mathrm{~d}$ before nonpregnancy diagnosis (NPD) to ensure that nonpregnant cows receive TAI as soon as possible (Chebel et al., 2003; Fricke et al., 2003; Lopes et al., 2013).

For farms that enroll cohorts of cows in a resynchronization of ovulation protocol on a weekly basis, an effective strategy to minimize the interbreeding interval of TAI services is to initiate the Ovsynch protocol (GnRH, 7 d later $\mathrm{PGF}_{2 \alpha}, 56 \mathrm{~h}$ later $\mathrm{GnRH}$, and 16 to $20 \mathrm{~h}$ later TAI) $25 \pm 3 \mathrm{~d}$ after AI (hereafter referred to as Resynch-25), which results in an interbreeding interval of $35 \pm 3 \mathrm{~d}$. A caveat of this protocol is that the GnRH treatment $25 \pm 3$ d after AI may reduce estrus expression because many cows are expected to receive the treatment when a follicle capable of ovulating in response to a $\mathrm{GnRH}$-induced $\mathrm{LH}$ surge is present on the ovaries. In cattle, a GnRH-induced LH surge causes an immediate reduction in estradiol production by the dominant follicle (Berndtson et al., 1995; Komar et al., 2001; Jo and Fortune, 2003), which can prevent the estradiol surge responsible for estrus behavior. Indeed, previous research has shown that fewer cows are detected in estrus when GnRH is given to cows 17 to $32 \mathrm{~d}$ after AI (Chebel et al., 2003; Mendonça et al., 2012; Bruno et al., 2014). Another inconvenience associated with the Resynch-25 protocol is that because the pregnancy status of cows is unknown $25 \pm 3 \mathrm{~d}$ after AI, a substantial proportion of the cows that receive the first GnRH treatment are pregnant. These unnecessary treatments increase the cost and burden (i.e., labor and cow disruption) of the reproductive management program. Thus, removing the first GnRH treatment of the protocol may be an alternative strategy to reduce the interbreeding interval without disrupting re-insemination at estrus and eliminating the treatment of pregnant cows.

The first GnRH of the Resynch-25 protocol is meant to induce the emergence of a new follicular wave that will give rise to the ovulatory follicle and the formation of a new corpus luteum (CL) after ovulation (Pursley et al., 1995). Therefore, removing the first $\mathrm{GnRH}$ of the Resynch-25 protocol may reduce the synchrony of ovulation, fail to promote a proper endocrine environment for follicle growth, and result in poorer oocyte quality because of an extended period of dominance of the ovulatory follicle. Indeed, P/AI of cows that ovulate to the first GnRH treatment of Ovsynch-like protocols is greater than that of cows that fail to ovulate (Chebel et al., 2003; Galvão et al., 2007; Rutigliano et al., 2008; Bisinotto et al., 2010; Keskin et al., 2010; Giordano et al., 2012d). Nonetheless, the detrimental effects of lack of ovulation may be less relevant when initiating Resynch $25 \pm 3 \mathrm{~d}$ after AI than when initiating the protocol at other intervals after AI (e.g., $32 \pm 3$ or $39 \pm$ $3 \mathrm{~d}$ ) or when a group of cows is initiated in the protocol at a wider range of days after AI. This is because at $32 \pm 3 \mathrm{~d}$ after $\mathrm{AI}$, when cows would receive the $\mathrm{PGF}_{2 \alpha}$ treatment of the Resynch-25 protocol, 60 to $85 \%$ of the nonpregnant cows present a functional CL (Giordano et al., 2012d, 2015; Bruno et al., 2014; Wijma et al., 2015) and almost all cows present an active follicle with potential to continue growing after a $\mathrm{PGF}_{2 \alpha}$ treatment (Wijma et al., 2015). Moreover, the ovulatory response to the first GnRH of the Resynch-25 protocol rarely exceeds $\sim 40$ to $60 \%$ (Giordano et al., 2012c; Lopes et al., 2013; Bruno et al., 2014), resulting in not all cows being properly synchronized $7 \mathrm{~d}$ later.

Another advantage of management strategies aimed at reducing the interbreeding interval of TAI services is that NPD is usually conducted through transrectal ultrasonography (Chebel et al., 2003; Fricke et al., 2003; Giordano et al., 2015). This method of pregnancy testing allows the determination of the ovarian status of cows with minimal effort. Anticipating that the use of the Resynch-25 protocol without the GnRH treatment $25 \pm 3 \mathrm{~d}$ after AI could result in fewer cows at the appropriate stage of the estrous cycle at NPD; using treatments tailored to the ovarian status of cows could help maximize P/AI to TAI services (Giordano et al., 2016). For example, completing the Resynch-25 protocol only in cows that present a CL and a putative ovulatory follicle at NPD could result in reasonable P/ AI. Conversely, cows without a CL or a putative ovulatory follicle (or both) may benefit from re-enrollment in a synchronization of ovulation treatment including progesterone (P4) supplementation (Bisinotto et al., 2015; Giordano et al., 2016) through improved synchrony of ovulation and a better endocrine environment before TAI.

Thus, our objectives were to evaluate the effect of removing the first GnRH of the Resynch-25 protocol on the pattern of re-insemination, ovarian responses before and after the protocol, and P/AI. We hypothesized that removing the GnRH treatment $25 \pm 3 \mathrm{~d}$ after AI would result in re-insemination of more cows upon detection of estrus. A secondary hypothesis was that the expected reduction in $\mathrm{P} / \mathrm{AI}$ for TAI services in cows that did not receive the $\mathrm{GnRH}$ treatment would not reduce the overall proportion of pregnant cows. We expected that cows pregnant after insemination at detected estrus would compensate for the reduced fertility to TAI services.

\section{MATERIALS AND METHODS}

This experiment was conducted from March 2015 to December of 2016 at the Dairy Unit of the Cornell Uni- 
versity Ruminant Center (Harford, NY). All procedures were approved by the Animal Care and Use Committee of Cornell University.

Cows were housed in free stall barns and were fed a TMR once a day with ad libitum access to feed and water. The diet was formulated to meet or exceed nutrient requirements for lactating dairy cows producing $45 \mathrm{~kg}$ of milk per day (Cornell Net Carbohydrate and Protein System). Cows were milked thrice daily at approximately 8-h intervals and received recombinant bST (500 mg of Sometribove zinc; Posilac, Elanco Animal Health, Indianapolis, IN) at 14-d intervals beginning at $60 \pm 3$ DIM until dry off.

Cows received the first service postpartum at 64 \pm 3 DIM after synchronization of ovulation with the Presynch-Ovsynch protocol $\mathrm{PGF}_{2 \alpha}, 14$ d later $\mathrm{PGF}_{2 \alpha}$, 12 d later GnRH, 7 d later $\mathrm{PGF}_{2 \alpha}, 56$ h later $\mathrm{GnRH}$, and 16 to $18 \mathrm{~h}$ later fixed time AI (Moreira et al., 2001)]. Ten percent of the cows did not complete the synchronization protocol and received the first service at detected estrus after the second $\mathrm{PGF}_{2 \alpha}$ treatment of Presynch because of management decisions from the farm manager.

Every Monday, the cohort of cows at $18 \pm 3 \mathrm{~d}$ after AI were blocked by parity (primiparous vs. multiparous) and randomly assigned to receive (G25, n $=1,100)$ or not receive (NoG25, $\mathrm{n}=1,098) \mathrm{GnRH}$ (Cystorelin, $100 \mu \mathrm{g}$, Merial LLC, Duluth, GA) treatment $25 \pm 3 \mathrm{~d}$ after AI (Figure 1). Cows could have been enrolled in either one of the treatments more than once. At $32 \pm 3$ d after AI, NPD was performed by transrectal ultrasonography (Ibex Pro, Ibex, Loveland, $\mathrm{CO}$ ) in cows from both treatments not previously reinseminated at detected estrus. A cow was considered pregnant if a viable embryo with a heartbeat or uterine fluid and a CL $\geq 15 \mathrm{~mm}$ were observed. Pregnant cows received no further treatment, whereas nonpregnant cows from both treatments (G25 and NoG25) were classified based on the ovarian structures present. Cows from the G25 and NoG25 treatments with at least 1 CL $\geq 15 \mathrm{~mm}$ and a follicle $\geq 10 \mathrm{~mm}$ in diameter received a $\mathrm{PGF}_{2 \alpha}$ (Estrumate, $500 \mu \mathrm{g}$, Merck Animal Health, Summit, NJ) treatment immediately after NPD, a second $\mathrm{PGF}_{2 \alpha}$ treatment $24 \mathrm{~h}$ later, GnRH $32 \mathrm{~h}$ after the second $\mathrm{PGF}_{2 \alpha}$ treatment, and TAI 16 to $18 \mathrm{~h}$ later (Figure 1). Cows from the G25 and NoG25 treatments that did not meet these criteria received a modified Ovsynch protocol with $2 \mathrm{PGF}_{2 \alpha}$ treatments and $\mathrm{P} 4$ supplementation through an intravaginal $\mathrm{P} 4$ releasing device (Eazi-Breed CIDR, Zoetis Animal Health, Florham Park, NJ) from the time of NPD to the first $\mathrm{PGF}_{2 \alpha}$ of the protocol [GnRH plus controlled internal drug release insert (CIDR) insertion, $7 \mathrm{~d}$ later $\mathrm{PGF}_{2 \alpha}$ and CIDR removal, $24 \mathrm{~h}$ later $\mathrm{PGF}_{2 \alpha}, 32 \mathrm{~h}$ later $\mathrm{GnRH}$, and 16 to $18 \mathrm{~h}$ later TAI; Figure 1].

For the G25 treatment, 272 cows with a CL and 53 cows without a CL received TAI, whereas for the NoG25 treatment 194 cows with a CL and 78 cows without a CL received TAI.

All cows detected in estrus after AI (before or after enrollment) were immediately inseminated. Detection of estrus was conducted through visual observation twice a day for $\sim 30$ to 45 min per session by the technician in charge of implementing the farm reproductive management program (i.e., AI, hormonal treatments, and assisting research personnel during pregnancy testing). Farm personnel in charge of moving cows to and from the parlor and milking also recorded estrus events.

Reconfirmation of pregnancy was performed at 63 $\pm 3 \mathrm{~d}$ after AI by transrectal palpation of the uterine contents. Pregnancy loss was defined as a negative pregnancy outcome at re-confirmation of pregnancy for a cow pregnant at the initial pregnancy examination or when a cow received insemination at detected estrus between the 2 pregnancy examinations.

\section{Evaluation of Ovarian Responses}

In a subgroup of cows $(\mathrm{n}=362)$ from each treatment $(\mathrm{G} 25=166$, NoG25 = 196), ovarian responses were monitored by transrectal ultrasonography following a Monday, Wednesday, and Friday schedule (enrollment and NPD were performed on Mondays) from $18 \pm 3$ d after AI until cows were either diagnosed pregnant or re-inseminated. Two hundred seventy-two cows were either detected in estrus and inseminated before NPD or were pregnant; thereby, the final number of cows with data available from enrollment until TAI was 46 and 44 for the G25 and NoG25 treatment, respectively.

At each examination, the location and size (diameter) of follicles $\geq 8 \mathrm{~mm}$ and any CL present was recorded on an individual ovarian map. All measurements were performed using the ultrasound machine internal digital calipers. Follicle and CL diameter was the average of the 2 longest perpendicular measurements. Ovulation was defined as the disappearance of at least 1 putative ovulatory follicle $\geq 10 \mathrm{~mm}$ between 2 consecutive examinations. The day of ovulation was defined as the day previous to the examination when follicle disappearance was detected. Ovulations detected up to $48 \mathrm{~h}$ after the GnRH treatment $25 \pm 3 \mathrm{~d}$ after AI were considered induced by $\mathrm{GnRH}$, whereas ovulations before $\mathrm{GnRH}$ treatment or more than $48 \mathrm{~h}$ after $\mathrm{GnRH}$ treatment were considered spontaneous ovulations. Follicles were considered active (i.e., growing or static phase of development) when their diameter was $\geq 10 \mathrm{~mm}$ and 
either continued to grow or did not present 2 consecutive reductions in size in 3 consecutive examinations.

\section{Blood Sample Collection}

Blood samples were collected at the time of the transrectal ultrasonography examination from the subgroup of cows in which ovarian responses were monitored (G25 $=166 ;$ NoG25 = 196). Blood samples were collected using 8-mL serum separator tubes (BD Vacutainer, Franklin Lakes, NJ) via puncture of the coccygeal vein or artery and were used to determine circulating concentrations of P4. Samples were centrifuged at 1,700 $\times \mathrm{g}$ for $20 \mathrm{~min}$ at room temperature within $2 \mathrm{~h}$ of collection. Serum was harvested and transferred into different storage vials and stored at $-20^{\circ} \mathrm{C}$ until assays were performed.

\section{Determination of Progesterone Concentrations}

Progesterone concentrations in serum were determined in duplicate using a commercial solid-phase,
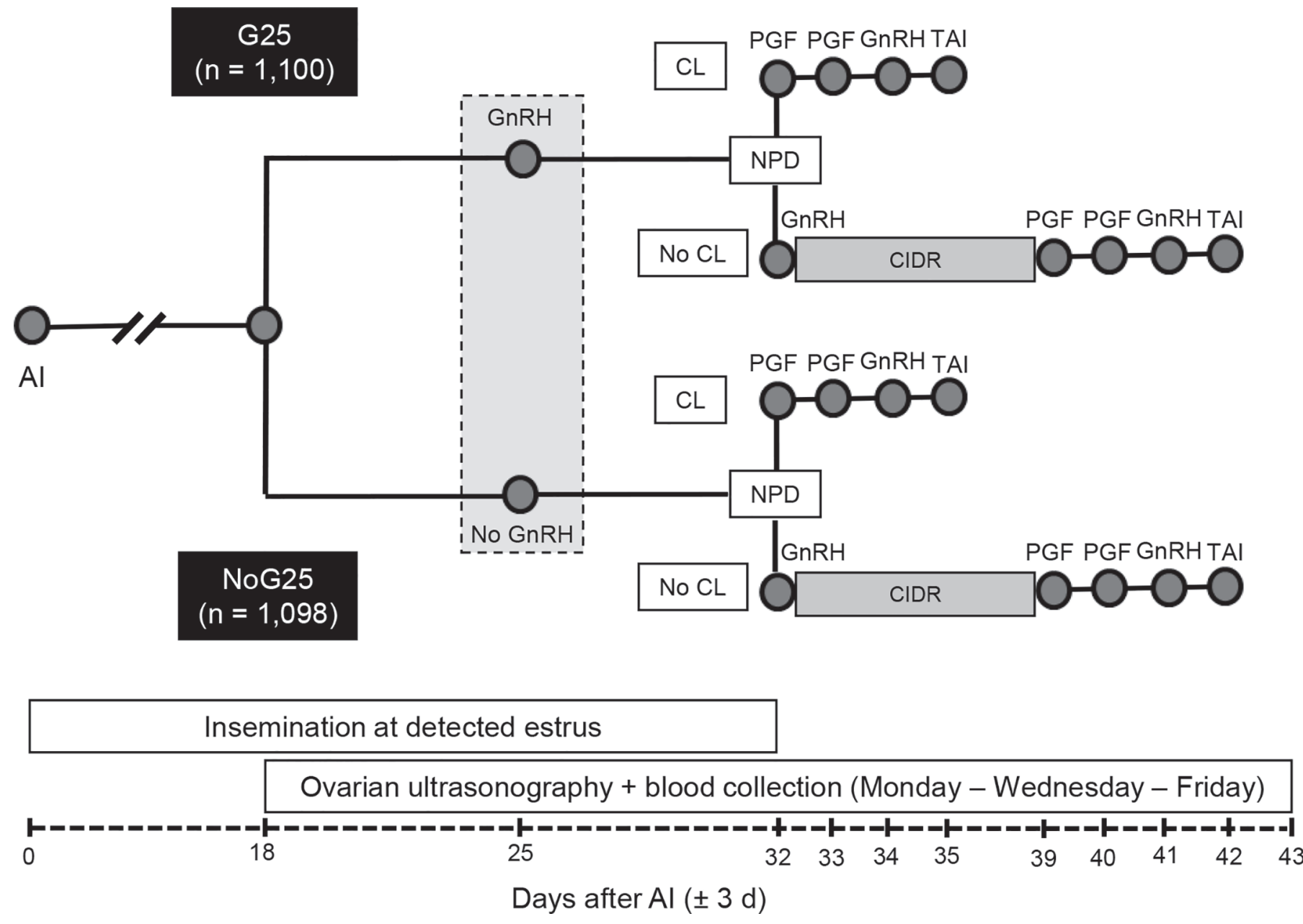

Figure 1. Graphical depiction of experimental procedures. Every Monday, cows at $18 \pm 3 \mathrm{~d}$ after AI (first or second and greater) were blocked by parity (primiparous vs. multiparous) and randomly assigned to receive (G25 treatment; $\mathrm{n}=1,100)$ or not receive (NoG25 treatment; $\mathrm{n}=1,098) \mathrm{GnRH}$ treatment $25 \pm 3 \mathrm{~d}$ after AI. Nonpregnancy diagnosis was performed $32 \pm 3 \mathrm{~d}$ after AI by transrectal ultrasonography in cows from both treatments not previously re-inseminated in estrus. Nonpregnant cows from both treatments were classified based on the ovarian structures present. Cows with at least 1 corpus luteum (CL) $\geq 15 \mathrm{~mm}$ and a follicle $\geq 10 \mathrm{~mm}$ in diameter (G25 = 325 and NoG25 = 272) received a $\mathrm{PGF}_{2 \alpha}$ treatment immediately after nonpregnancy diagnosis (NPD), a second $\mathrm{PGF}_{2 \alpha}$ treatment $24 \mathrm{~h}$ later, GnRH $32 \mathrm{~h}$ after the second $\mathrm{PGF}_{2 \alpha}$ treatment, and timed $\mathrm{AI} 16$ to $18 \mathrm{~h}$ later. Cows that did not meet these criteria $(\mathrm{G} 25=53$ and NoG25 = 78) were treated with the Ovsynch protocol with $2 \mathrm{PGF}_{2 \alpha}$ treatments and progesterone supplementation [GnRH and controlled internal drug release (CIDR) insertion at NPD, CIDR removal and $\mathrm{PGF}_{2 \alpha} 7 \mathrm{~d}$ later, $\mathrm{PGF}_{2 \alpha} 1 \mathrm{~d}$ later, GnRH $32 \mathrm{~h}$ after the second PGF $\mathrm{P}_{2 \alpha}$, and fixed time AI 16 to $18 \mathrm{~h}$ after the $\mathrm{GnRH}$ ]. In a subgroup of cows $(\mathrm{G} 25=166$ and NoG25 = 196), ovarian responses were monitored by transrectal ultrasonography following a Monday, Wednesday, Friday schedule (enrollment and nonpregnancy diagnosis were performed on Mondays) from $18 \pm 3$ d after AI until cows were either diagnosed pregnant or re-inseminated. At the time of transrectal ultrasonography, a blood sample was obtained to measure circulating concentrations of progesterone. TAI = timed AI. 
no-extraction RIA (ImmuChem Coated Tube, MP Biomedicals, Costa Mesa, CA). To assess precision of the assay, control samples with high $(4.5 \mathrm{ng} / \mathrm{mL})$ and low $(0.3 \mathrm{ng} / \mathrm{mL})$ concentrations of $\mathrm{P} 4$ were included at the beginning and end of each assay ( $\mathrm{n}=7$ assays). Average detection limit for the P4 assay was $0.1 \mathrm{ng} /$ $\mathrm{mL}$. Average intraassay CV for the high-concentration sample was $13 \%$, whereas the interassay CV was $16 \%$. For the low-concentration sample the average intraassay CV was $22 \%$, whereas the interassay CV was $26 \%$.

Circulating concentrations of $\mathrm{P} 4$ were used to determine the presence or absence of a functional CL and luteal regression. The presence of a functional CL was defined as circulating concentrations of $\mathrm{P} 4 \geq 0.5 \mathrm{ng} / \mathrm{mL}$ at time points of interest, whereas luteal regression was defined as drop in circulating concentrations of $\mathrm{P} 4$ to $<0.5 \mathrm{ng} / \mathrm{mL}$.

\section{Statistical Analysis}

The experiment was conducted as a randomized complete block design using parity (primiparous vs. multiparous) as blocking factor, and number of AI services as stratification factor. Because the experimental unit was the AI service after enrollment, cows were randomized each time they reached $18 \pm 3 \mathrm{~d}$ after a previous AI.

A sample size calculation was performed using the sample size calculation option of WinPepi version 11.51 (Abramson, 2011). Based on an expected difference between treatments in the proportion of cows detected in estrus of 10 percentage points for cows that received GnRH treatment at the same range of days after AI (Bruno et al., 2014), a total of 325 cows per treatment was needed for a 1-tailed test with probability of type I error rate of $5 \%$ and probability of type II error rate of $20 \%$. Moreover, because P/AI for cows with a CL at NPD that did not receive GnRH was a secondary outcome of interest for this experiment, we planned on enrolling more cows to have sufficient experimental units (i.e., AI services) to detect a difference in $\mathrm{P} / \mathrm{AI}$ ranging from 11 to 12 percentage points when $\mathrm{P} / \mathrm{AI}$ for TAI services in cows with a CL in the G25 treatment was $35 \%$. A total of 176 to 212 cows per treatment were needed for a 1-tailed test with probability of type I error rate of $5 \%$ and probability of type II error rate of $20 \%$. We did not expect to detect a difference in $\mathrm{P} /$ AI for cows inseminated after a detected estrus or cows without a CL at NPD. A 1-tailed test was used for the analysis of proportion of cows detected in estrus and P/ AI for cows with CL at NPD because in both cases the hypothesis was that the difference between treatments would be in one direction. Specifically, we anticipated observing a greater proportion of cows detected in estrus in the NoG25 treatment based on experiments that reported a reduction in estrus expression in cows treated with GnRH (Bruno et al., 2014). For P/AI in cows with a CL, we anticipated observing greater $\mathrm{P} / \mathrm{AI}$ for the G25 treatment because cows that ovulated in response to the $\mathrm{GnRH}$ treatment to induce a follicular wave in Ovsynch-type protocols had greater P/AI in previous experiments (Chebel et al., 2003; Bisinotto et al., 2010; Keskin et al., 2010).

Binary outcomes (P/AI, proportion of cows detected in estrus, proportion of cows with a CL at NPD, pregnancy loss from $32 \pm 3$ to $63 \pm 3 \mathrm{~d}$ after AI, ovulation, presence of an active follicle at NPD, and proportion of cows with $\mathrm{P} 4 \geq 0.5 \mathrm{ng} / \mathrm{mL}$ at NPD) were analyzed using logistic regression with the GLIMMIX procedure of SAS (version 9.4, SAS Institute Inc., Cary, NC). Treatment and parity (primiparous vs. multiparous) were included as fixed effects, and cow was included as random effect when applicable (proportion of cows detected in estrus, proportion of cows with a CL at NPD). Days in milk at enrollment and season at the time of insemination [warm (June, July, and August) vs. cold (September to May)] were offered to the initial models. Both DIM and season were removed from all final models because $P>0.10$. Luteal regression and presence of an active follicle at the time of GnRH treatment $25 \pm 3$ d after AI were analyzed with the Fisher exact test using the FREQ procedure of SAS because in one of the groups $100 \%$ of the cows presented luteal regression or an active follicle.

Data for circulating concentrations of $\mathrm{P} 4$, follicle size, days to ovulation, and days after the largest active follicle present $25 \pm 3$ and $32 \pm 3 \mathrm{~d}$ after AI reached $10 \mathrm{~mm}$ were analyzed by ANOVA with the MIXED procedure of SAS including treatment and parity as fixed effects. Normality and homoscedasticity of residuals were assessed using graphical methods generated with the residual option of the MIXED procedure of SAS. Because progesterone concentration data were not normally distributed, square root transformation of the data was used. Days to ovulation and days after the largest active follicle present $25 \pm 3$ and $32 \pm 3 \mathrm{~d}$ after AI reached $10 \mathrm{~mm}$ did not follow a normal distribution and could not be corrected through data transformation. Therefore, data were analyzed using the KruskalWallis test with the NPAR1WAY procedure of SAS.

Cox's proportional hazards regression run with the PHREG procedure of SAS was used to determine the hazard of ovulation and re-insemination after AI. Treatment and parity were included as fixed effects, and cow as a random effect (for hazard of re-insemination only). Kaplan-Meier survival curves were generated to illustrate the hazard of re-insemination in estrus after AI 
using the Survival Analysis option of MedCalc (MedCalc Software bvba, Ostend, Belgium).

All results are presented as arithmetic means $\pm \mathrm{SE}$ generated with the MEANS procedure of SAS. All explanatory variables were considered significant if $P \leq$ 0.05 , whereas $P$-values $>0.05$ and $\leq 0.10$ were considered a tendency.

\section{RESULTS}

\section{Re-insemination Dynamics and Pregnancy per Al}

Forty-four percent of the cows that were enrolled $18 \pm 3 \mathrm{~d}$ after AI were considered pregnant based on transrectal ultrasonography $32 \pm 3 \mathrm{~d}$ after AI. Pregnancy per AI for these cows was similar $(P=0.81)$ for the G25 (44.4\%; 483/1,088) and the NoG25 (43.9\%; 479/1,092) treatment.

A greater proportion of cows were inseminated $(P$ $<0.01$ ) after a detected estrus in the NoG25 than in the G25 treatment (Table 1). Parity also had an effect on the proportion of cows that received AI after estrus detection [primiparous $=55.3 \%(140 / 253)$ and multiparous $=47.3 \%(435 / 919) ; P=0.03]$. The hazard of insemination after estrus detection was greater $(P$ $=0.04$ ) for cows in the NoG25 treatment [hazard ratio $(\mathbf{H R})=1.20,95 \%$ CI: 1.01 to 1.43; Figure 2]. Median time to re-insemination at detected estrus for the NoG25 treatment was 31 d (95\% CI: 27 to 35), whereas it could not be calculated for the G25 treatment because less than $50 \%$ of the cows were re-inseminated at detected estrus. Further, mean days to detection of estrus were $23.2 \pm 0.3$ and $22.5 \pm 0.3$ for the NoG25 and G25 treatment, respectively. Primiparous cows had greater $(P=0.01)$ hazard of insemination after estrus detection than multiparous cows $(\mathrm{HR}=1.35,95 \% \mathrm{CI}$ : 1.07 to 1.71 ). Mean days to estrus detection were 22.1

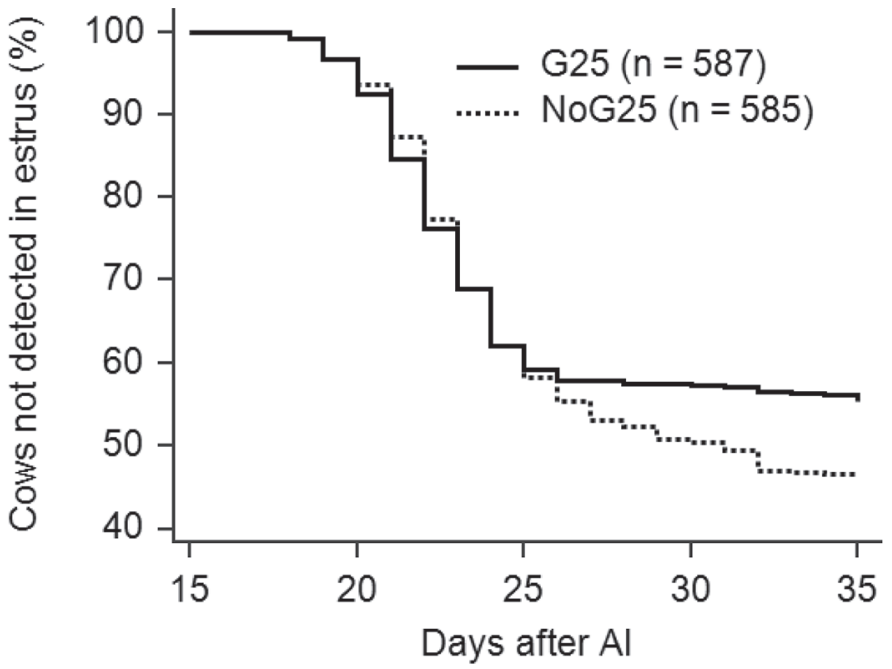

Figure 2. Kaplan-Meier survival curves for time to insemination at detected estrus from enrollment $(18 \pm 3 \mathrm{~d}$ after AI) until nonpregnancy diagnosis (32 $\pm 3 \mathrm{~d}$ after AI) for cows that received (G25) or did not receive (NoG25) the GnRH treatment. The hazard of insemination at detected estrus was greater $(P=0.04)$ for the NoG25 treatment (hazard ratio $=1.20,95 \%$ CI: 1.01 to 1.43 ). Median time to re-insemination at detected estrus for the NoG25 treatment was 31 d (95\% CI: 27 to 35), whereas it could not be calculated for the G25 treatment because less than $50 \%$ of the cows were re-inseminated at detected estrus.

$\pm 0.4 \mathrm{~d}$ primiparous cows and $23.1 \pm 0.2 \mathrm{~d}$ for multiparous cows.

In spite of the difference in the proportion of cows detected in estrus and hazard ratio for detection of estrus before NPD, the hazard of re-insemination for all services combined (at detected estrus and TAI) was similar $(P=0.80)$ for both treatments $(\mathrm{HR}=1.02$, 95\% CI: 0.90 to 1.14). Median days to re-insemination were 34 and $31 \mathrm{~d}$ for the G25 and NoG25 treatment, respectively, whereas mean days to re-insemination were

Table 1. Proportion of cows inseminated at detected estrus before nonpregnancy diagnosis (NPD) and proportion of cows with or without a corpus luteum (CL) $\geq 15 \mathrm{~mm}$ at NPD for the G25 and NoG25 treatment ${ }^{1}$

\begin{tabular}{lccc}
\hline \multirow{2}{*}{ Item } & \multicolumn{2}{c}{ Treatment } & \\
\cline { 2 - 3 } & $\mathrm{G} 25$ & NoG25 & \multirow{2}{*}{$P$-value } \\
\hline Estrus detection and AI before NPD & $\%$ (no./no. $)$ & $\%($ no. $/$ no. $)$ & $<0.01$ \\
CL $\geq 15 \mathrm{~mm}$ at NPD & 44.6 & 53.5 & $<0.001$ \\
No CL $\geq 15 \mathrm{~mm}$ at NPD & $(262 / 587)$ & $(313 / 585)$ & $<0.001$ \\
& $(272 / 325)$ & $(194 / 272)$ & 28.6 \\
\end{tabular}

\footnotetext{
${ }^{1}$ Treatment: $18 \pm 3 \mathrm{~d}$ after AI, cows were randomly assigned to receive (G25) or not (NoG25) GnRH $25 \pm 3 \mathrm{~d}$ after AI. At $32 \pm 3 \mathrm{~d}$ after AI, nonpregnant cows from both treatments with at least $1 \mathrm{CL} \geq 15 \mathrm{~mm}$ received a $\mathrm{PGF}_{2 \alpha}$ treatment immediately after NPD, a second $\mathrm{PGF}_{2 \alpha}$ treatment $24 \mathrm{~h}$ later, GnRH $32 \mathrm{~h}$ after the second $\mathrm{PGF}_{2 \alpha}$ treatment, and timed AI 16 to $18 \mathrm{~h}$ later. Cows without a CL received a modified Ovsynch protocol with $2 \mathrm{PGF}_{2 \alpha}$ treatments and progesterone supplementation.
} 
Table 2. Pregnancy per AI and pregnancy loss for cows that received the G25 and NoG25 treatment ${ }^{1}$

\begin{tabular}{|c|c|c|c|}
\hline \multirow[b]{2}{*}{ Item $^{2}$} & \multicolumn{2}{|c|}{ Treatment } & \multirow[b]{2}{*}{$P$-value } \\
\hline & $\begin{array}{c}\mathrm{G} 25 \\
\%(\text { no. } / \text { no. })\end{array}$ & $\begin{array}{c}\text { NoG25 } \\
\% \text { (no./no.) }\end{array}$ & \\
\hline Overall $\mathrm{P} / \mathrm{AI} 32 \pm 3 \mathrm{~d}$ after $\mathrm{AI}$ for all inseminations & $\begin{array}{c}39.6 \\
(226 / 571)\end{array}$ & $\begin{array}{c}39.0 \\
(223 / 572)\end{array}$ & 0.80 \\
\hline Overall $\mathrm{P} / \mathrm{AI} 63 \pm 3 \mathrm{~d}$ after $\mathrm{AI}$ for all inseminations ${ }^{3}$ & $\begin{array}{c}36.2 \\
(205 / 566)\end{array}$ & $\begin{array}{c}35.6 \\
(202 / 567)\end{array}$ & 0.76 \\
\hline Overall pregnancy loss for all inseminations ${ }^{4}$ & $\begin{array}{c}7.2 \\
(16 / 223)\end{array}$ & $\begin{array}{c}7.3 \\
(16 / 218)\end{array}$ & 0.94 \\
\hline $\mathrm{P} / \mathrm{AI}$ for inseminations at detected estrus & $\begin{array}{l}38.4 \\
(99 / 258)\end{array}$ & $\begin{array}{c}42.9 \\
(132 / 308)\end{array}$ & 0.30 \\
\hline $\mathrm{P} / \mathrm{AI}$ for cows with $\mathrm{CL} \geq 15 \mathrm{~mm}$ at $\mathrm{NPD}$ & $\begin{array}{c}40.6 \\
(106 / 261)\end{array}$ & $\begin{array}{l}32.8 \\
(62 / 189)\end{array}$ & 0.05 \\
\hline $\mathrm{P} / \mathrm{AI}$ for cows without a $\mathrm{CL} \geq 15 \mathrm{~mm}$ at $\mathrm{NPD}$ & $\begin{array}{l}40.4 \\
(21 / 52)\end{array}$ & $\begin{array}{l}36.7 \\
(29 / 75)\end{array}$ & 0.82 \\
\hline
\end{tabular}

${ }^{1}$ Treatment: $18 \pm 3 \mathrm{~d}$ after AI, cows were randomly assigned to receive (G25 treatment) or not (NoG25 treatment) GnRH $25 \pm 3$ d after AI. At $32 \pm 3$ d after AI, nonpregnant cows from both treatments with at least 1 corpus luteum (CL) $\geq 15 \mathrm{~mm}$ received a $\mathrm{PGF}_{2 \alpha}$ treatment immediately after $\mathrm{NPD}$, a second $\mathrm{PGF}_{2 \alpha}$ treatment $24 \mathrm{~h}$ later, $\mathrm{GnRH} 32 \mathrm{~h}$ after the second $\mathrm{PGF}_{2 \alpha}$ treatment, and timed $\mathrm{AI} 16$ to $18 \mathrm{~h}$ later. Cows without a CL received a modified Ovsynch protocol with $2 \mathrm{PGF}_{2 \alpha}$ treatments and progesterone supplementation.

${ }^{2} \mathrm{P} / \mathrm{AI}=$ pregnancy per $\mathrm{AI} ; \mathrm{NPD}=$ nonpregnancy diagnosis.

${ }^{3}$ Five cows from the G25 treatment and 5 cows from the NoG25 treatment exited the herd before reconfirmation of pregnancy.

${ }^{4}$ Three pregnant cows from the G25 treatment and 5 cows from the NoG25 treatment exited the herd before reconfirmation of pregnancy. Pregnancy loss from $32 \pm 3 \mathrm{~d}$ after AI to the day the herd exited was not observed for these cows.

$30.3 \pm 0.3$ and $29.9 \pm 0.3 \mathrm{~d}$ for the G25 and NoG25 treatment, respectively.

Among cows diagnosed nonpregnant $32 \pm 3 \mathrm{~d}$ after AI, a greater $(P<0.001)$ proportion of cows in the NoG25 treatment did not have a CL $\geq 15 \mathrm{~mm}$ at NPD (Table 1$)$. Parity did not affect $(P=0.89)$ the proportion of cows without a CL $\geq 15 \mathrm{~mm}$ at NPD.

Pregnancy per AI for all AI services combined (after detected estrus and TAI $)$ did not differ $(P=0.80)$ between treatments (Table 2$)$ but was greater $(P<0.01)$ for primiparous $(46.8 \%$; $117 / 250)$ than multiparous cows $(37.2 \% ; 332 / 893)$. Further, P/AI did not differ for the G25 and NoG25 treatments for cows that received AI after a detected estrus $(P=0.30)$ or for cows without a $\mathrm{CL} \geq 15 \mathrm{~mm}$ at NPD that received TAI $(P$ $=0.82$; Table 2 ). Pregnancy per AI for cows with a CL $\geq 15 \mathrm{~mm}$ at NPD that received TAI was greater $(P=$ 0.05 ) for the G25 than the NoG25 treatment (Table 2).

Five cows from the G25 treatment and 5 cows from the NoG25 treatment exited the herd before pregnancy reconfirmation. Pregnancy per AI $63 \pm 3$ d after AI was not different $(P=0.76)$ between treatments $(\mathrm{G} 25$ $=36.2 \%$ and NoG25 $=35.6 \%)$ and was greater $(P<$ $0.01)$ for primiparous $(43.0 \%, 107 / 249)$ than multiparous cows $(34.1 \%, 301 / 583)$. Pregnancy loss from the initial pregnancy evaluation at $32 \pm 3$ after AI until pregnancy reconfirmation $63 \pm 3 \mathrm{~d}$ after AI for all inseminations was similar $(P=0.94)$ for both treatments
(Table 2). Further, pregnancy loss was not different between the G25 and the NoG25 treatments for cows inseminated at detected estrus (G25 $=7 \%$ and NoG25 $=6 \% ; P=0.77)$, cows that had a CL $\geq 15 \mathrm{~mm}$ at NPD and received TAI $(\mathrm{G} 25=9 \%$ and NoG25 $=8 \% ; P=$ 0.94 ), and cows that did not have a CL $\geq 15 \mathrm{~mm}$ at NPD and received TAI (G25 $=0 \%$ and NoG25 $=11 \%$; $P=0.97)$.

\section{Ovarian Responses from Enrollment Until Nonpregnancy Diagnosis}

Out of 362 cows with data for ovarian responses, $42 \%(\mathrm{n}=153)$ were pregnant and $58 \%(\mathrm{n}=209)$ were nonpregnant $32 \pm 3 \mathrm{~d}$ after AI. Among nonpregnant cows, $57 \%(\mathrm{n}=119)$ were inseminated after detection of estrus before NPD and 43\% ( $\mathrm{n}=90 ; \mathrm{G} 25: \mathrm{n}=46$ and NoG25: $\mathrm{n}=44$ ) were diagnosed nonpregnant $32 \pm$ $3 \mathrm{~d}$ after AI. All cows diagnosed nonpregnant received TAI. Blood samples were not available for 2 cows (one from the G25 and one from the NoG25 treatment), but ovarian data collected by transrectal ultrasonography were included in the analysis.

The proportion of cows not re-inseminated at detected estrus that ovulated spontaneously from $18 \pm 3$ to $32 \pm 3 \mathrm{~d}$ after $\mathrm{AI}$ was not affected by treatment $(P=$ 0.20 ; Table 3$)$ or parity $(P=0.38)$. Including spontaneous and induced ovulations, a greater proportion $(P$ 
Table 3. Ovarian responses and response to resynchronization protocols from enrollment up to the time of nonpregnancy diagnosis (NPD) for cows in the G25 and NoG25 treatment ${ }^{1}$

\begin{tabular}{lccc}
\hline & \multicolumn{3}{c}{ Treatment } \\
\cline { 2 - 4 } Item & $\begin{array}{c}\text { G25 } \\
(\mathrm{n}=46)\end{array}$ & $\begin{array}{c}\text { NoG25 } \\
(\mathrm{n}=44)\end{array}$ & $P$-value \\
\hline Spontaneous ovulation before NPD (\%) & 22 & 36 & 0.20 \\
Ovulation after GnRH $25 \pm 3$ d after AI (\%) & 50 & - & - \\
Mean days to ovulation (d) & $25.9 \pm 0.4$ & $23.7 \pm 0.7$ & $<0.01$ \\
Active follicle at NPD (\%) & 91 & 96 & 0.67 \\
Active follicle size (mm) at NPD & $15.0 \pm 0.4$ & $16.5 \pm 0.6$ & 0.01 \\
Days since active follicle at NPD reached $\geq 10 \mathrm{~mm}$ & $4.0 \pm 0.3$ & $5.8 \pm 0.6$ & $<0.01$ \\
P4 $4^{3} \geq 0.5$ ng/mL at NPD (\%) & 83 & 73 & 0.38 \\
\hline
\end{tabular}

${ }^{1}$ Treatment: $18 \pm 3 \mathrm{~d}$ after AI, cows were randomly assigned to receive (G25 treatment) or not (NoG25 treatment) GnRH $25 \pm 3$ d after AI. At $32 \pm 3$ d after AI, nonpregnant cows from both treatments with at least 1 corpus luteum $(\mathrm{CL}) \geq 15 \mathrm{~mm}$ received a $\mathrm{PGF}_{2 \alpha}$ treatment immediately after $\mathrm{NPD}$, a second $\mathrm{PGF}_{2 \alpha}$ treatment $24 \mathrm{~h}$ later, GnRH $32 \mathrm{~h}$ after the second $\mathrm{PGF}_{2 \alpha}$ treatment, and timed AI 16 to $18 \mathrm{~h}$ later. Cows without a CL received a modified Ovsynch protocol with $2 \mathrm{PGF}_{2 \alpha}$ treatments and progesterone supplementation. Blood samples were not available for 2 cows ( 1 from each treatment).

${ }^{2}$ One cow in the G25 treatment ovulated on d 21 and after GnRH treatment $25 \pm 3 \mathrm{~d}$ after AI.

${ }^{3} \mathrm{P} 4=$ progesterone.

$<0.01)$ of cows ovulated in the G25 treatment $(72 \%)$ than the NoG25 treatment (36\%) from $18 \pm 3$ to $32 \pm$ $3 \mathrm{~d}$ after AI. For cows in the G25 treatment, $50 \%$ ovulated in response to the GnRH treatment given $25 \pm 3$ d after AI (Table 3$)$. Parity did not affect $(P=0.47)$ the proportion of cows that ovulated. Mean days from the previous AI to ovulation were greater $(P<0.01)$ for cows in the G25 (25.9 $\pm 0.4 \mathrm{~d}$; range: 21 to $30 \mathrm{~d})$ than the NoG25 treatment $(23.7 \pm 0.7 \mathrm{~d}$; range: 19 to 29 d; Table 3). From the time of enrollment until NPD, the hazard of ovulation was greater $(P=0.04)$ for cows in the G25 treatment ( $\mathrm{HR}=1.89,95 \% \mathrm{CI}: 1.05$ to 3.5; Figure 3). Median days to ovulation for the G25 treatment were $26 \mathrm{~d}$ (95\% CI: 26 to 30). Median days to ovulation could not be calculated for the NoG25 treatment because less than $50 \%$ of the cows ovulated.

For both treatments combined, 90\% (81/90) of the cows had an active follicle $25 \pm 3 \mathrm{~d}$ after AI. For cows in the G25 treatment only, the proportion of cows with an active follicle on the day of GnRH $25 \pm 3 \mathrm{~d}$ after AI was similar $(P=0.99)$ for cows that did $(100 \%)$ or did not $(96 \%)$ ovulate. Conversely, diameter of the largest active follicle was greater $(P<0.001)$ for cows that ovulated $(17.8 \pm 0.9 \mathrm{~mm}$, range $=10$ to $29 \mathrm{~mm})$ than for cows that failed to ovulate in response to $\mathrm{GnRH}$ $(13.7 \pm 0.7 \mathrm{~mm}$, range $=10$ to $20 \mathrm{~mm})$. The largest active follicle present $25 \pm 3 \mathrm{~d}$ after AI reached a size of $\geq 10 \mathrm{~mm}$ earlier $(P=0.02)$ in cows that ovulated $(5.6 \pm$ $0.4 \mathrm{~d}$ before $\mathrm{GnRH}$ ) than in cows that did not ovulate $(3.8 \pm 0.6 \mathrm{~d}$ before $\mathrm{GnRH})$. Further, the proportion of cows with $\mathrm{P} 4 \geq 1 \mathrm{ng} / \mathrm{mL}$ at the time of the $\mathrm{GnRH}$ treatment did not differ $(P=0.23)$ for the group that ovulated or did not ovulate after $\mathrm{GnRH}$ [ovulated $=$
$52 \%(12 / 23)$ and not ovulated $=70 \%(16 / 23)]$, but cows that ovulated tended $(P=0.07)$ to have lesser concentrations of $\mathrm{P} 4(2.1 \pm 0.6 \mathrm{ng} / \mathrm{mL})$ than cows that did not ovulate $(3.6 \pm 0.6 \mathrm{ng} / \mathrm{mL})$.

Treatment did not $(P=0.67)$ affect the proportion of cows with at least 1 active follicle at NPD (Table $3)$. Parity, however, tended $(P=0.07)$ to affect the proportion of cows with at least 1 active follicle at NPD

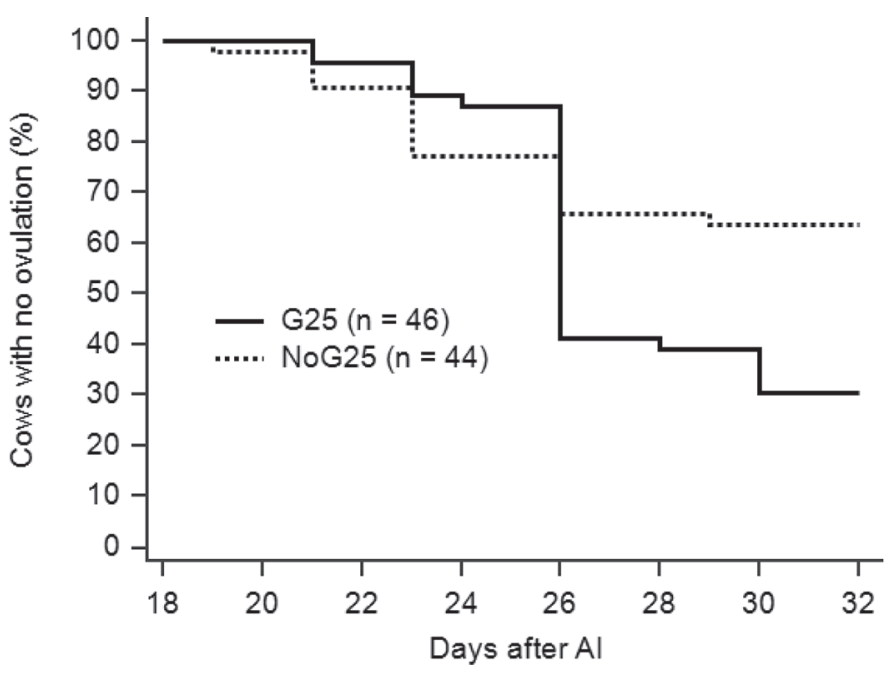

Figure 3. Kaplan-Meier survival curves for time to ovulation from enrollment (18 $\pm 3 \mathrm{~d}$ after AI) until nonpregnancy diagnosis $(32 \pm 3 \mathrm{~d}$ after AI) for cows that received (G25) or did not receive (NoG25) the GnRH treatment. The hazard of ovulation was greater $(P=0.04)$ for the G25 treatment (hazard ratio $=1.89,95 \%$ CI: 1.05 to 3.5 ). Median time to ovulation for the G25 treatment was 26 d (95\% CI: 26 to 30). Median time to ovulation could not be calculated for the NoG25 treatment because less than $50 \%$ of the cows ovulated. 
[primiparous $=80 \%(12 / 15)$ and multiparous $=95 \%$ $(71 / 75)]$. Size of the largest active follicle at NPD was greater $(P=0.01)$ for the NoG25 than for the G25 treatment (Table 3$)$ and was not affected $(P=0.11)$ by parity. Furthermore, mean days since the largest active follicle present at NPD reached a size of $\geq 10$ mm was greater $(P<0.01)$ for the NoG25 than for the G25 treatment (Table 3). A similar proportion of cows in both treatments $(P=0.38$; Table 3$)$ had $\mathrm{P} 4 \geq 0.5$ $\mathrm{ng} / \mathrm{mL}$ at NPD. Parity did not affect $(P=0.59)$ the proportion of cows with $\mathrm{P} 4 \geq 0.5 \mathrm{ng} / \mathrm{mL}$ at NPD.

Among cows with a CL $\geq 15 \mathrm{~mm}$ at NPD, those in the NoG25 treatment had greater $(P=0.03)$ concentrations of $\mathrm{P} 4$ at NPD than cows in the G25 treatment (Table 4). The proportion of cows with luteal regression from the time of NPD to the GnRH treatment before TAI was similar for both treatments $(P=0.97$; Table 4). Ninety-five percent and $100 \%$ of the cows had complete luteal regression in the G25 and NoG25 treatment, respectively. Likewise, mean size of the ovulatory follicle $1 \mathrm{~d}$ before TAI $(P=0.15)$ and the proportion of cows that ovulated after TAI $(P=0.35)$ were similar for both treatments (Table 4). For cows without a CL at NPD, treatment did not affect concentrations of P4 at NPD $(P=0.28)$, luteal regression before TAI $(P=$ $0.99)$, size of the putative ovulatory follicle $(P=0.68)$, or ovulation after TAI $(P=0.97$; Table 4$)$. Parity did not affect circulating concentrations of P4 at NPD $(P$ $>0.10)$, size of the ovulatory follicle $(P>0.10)$, or proportion of cows that ovulated after TAI $(P>0.10)$ in cows with or without a CL at NPD.

\section{DISCUSSION}

In the present experiment, we evaluated a management strategy that consisted of removing the first $\mathrm{GnRH}$ injection of the Resynch-25 protocol to avoid disrupting estrus expression after the previous insemination while achieving a short interval between TAI services (i.e., 35 $\pm 3 \mathrm{~d}$ ). A treatment to increase $\mathrm{P} / \mathrm{AI}$ of cows with no $\mathrm{CL}$ at NPD was also included because these cows were not expected to properly respond to the shortened protocol. In support of our hypotheses, removing the first GnRH of the Resynch-25 protocol affected the pattern of re-insemination and ovarian responses before NPD. Our current data also supported the hypothesis that a reduction would not occur in the overall proportion of pregnant cows (combining insemination of cows at detected estrus and TAI) despite a reduction in $\mathrm{P} / \mathrm{AI}$ for cows with a CL at NPD in the NoG25 treatment.

The different pattern of re-insemination after GnRH $25 \pm 3 \mathrm{~d}$ after $\mathrm{AI}$ and the greater hazard of AI at detected estrus for the NoG25 treatment supported the hypothesis that estrus expression would be limited by GnRH treatment. The reduction in the proportion of cows detected in estrus in the G25 treatment was similar to that observed ( $\sim 10$ percentage points) for cows that received $\mathrm{GnRH}$ in the same range of days after AI (Bruno et al., 2014). The most likely mechanism underlying the reduction in estrus expression was lack of an estradiol surge due to the shift from estradiol to progesterone secretion by the granulosa cells of the pre-ovulatory follicle in response to an LH surge (Berndtson et al., 1995; Komar et al., 2001; Jo and Fortune, 2003). Indeed, the pattern of estrus expression after AI clearly reflected the effect of $\mathrm{GnRH}$ treatment because it was similar for the 2 treatments up to $25 \mathrm{~d}$ after AI when the vast majority of cows in the G25 treatment received GnRH (data not shown).

The physiological response to treatments from $18 \pm$ 3 to $32 \pm 3 \mathrm{~d}$ after $\mathrm{AI}$ also reflected the effect of $\mathrm{GnRH}$ on ovarian responses. The proportion of cows that ovulated in response to $\mathrm{GnRH}$ was in agreement with previous experiments (Giordano et al., 2012c; Bruno et al., 2014) and was responsible for the greater proportion of cows with a CL at NPD in the G25 treatment. In-

Table 4. Ovarian responses and response to resynchronization protocols from the time of nonpregnancy diagnosis to the time of insemination for cows with or without a corpus luteum (CL) at nonpregnancy diagnosis that received the G25 and NoG25 treatment ${ }^{1}$

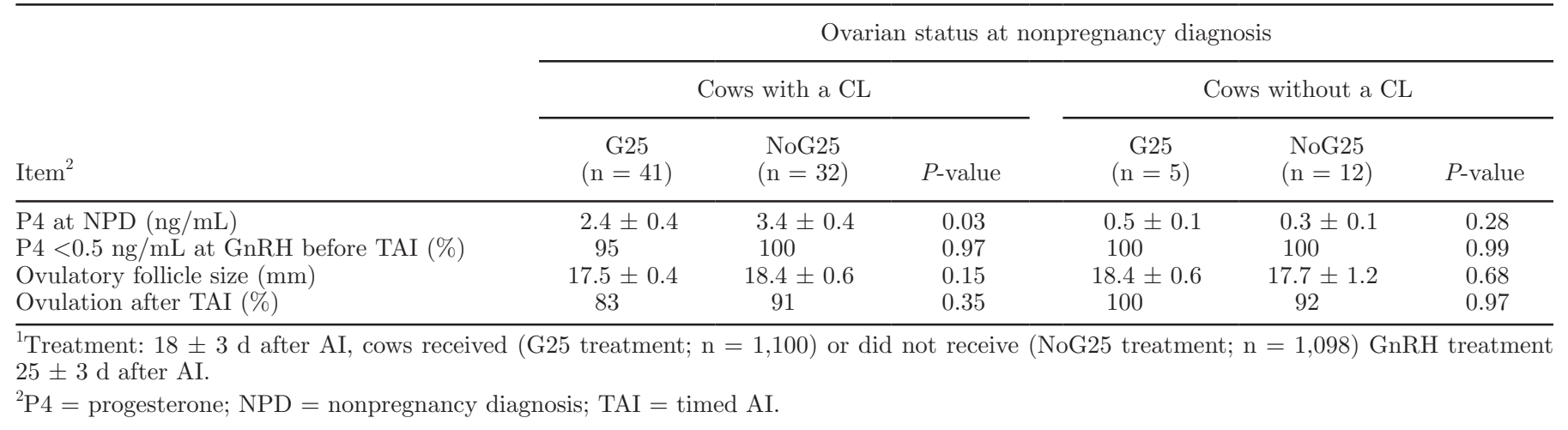


terestingly, the difference between treatments was only 12.7 percentage points, which may be a reflection of the substantial proportion of cows with a CL formed after the previous AI (data not shown) and the occurrence of spontaneous ovulation before NPD in $36 \%$ of the cows in the NoG25 treatment. Other factors may have been responsible for the small difference in the proportion of cows with a CL at NPD between treatments. For example, lack of response to $\mathrm{GnRH}$ in cows that did not have a CL formed after the previous AI or cows without spontaneous ovulation from 18 to $32 \mathrm{~d}$ after AI in the G25 treatment. For these cows, lack of ovulation in response to $\mathrm{GnRH}$ may have been due to the stage of follicle development at the time of GnRH treatment. Indeed, there was no difference in the proportion of cows with an active follicle but cows that ovulated had larger follicles than cows that did not ovulate. It is also possible that ovulation was suppressed by the negative effect of $\mathrm{P} 4$ on GnRH-induced LH release (Giordano et al., 2012a; Lima et al., 2013; Stevenson and Pulley, 2016) in cows with a CL formed after the previous AI (data not shown). In some of these cows, however, the CL present at the time of the GnRH injection could have regressed before NPD.

From a practical perspective, the greatest difference resulting from the 2 strategies compared in this experiment would likely be a different proportion of cows detected in estrus before NPD. This could translate into fewer cows needing resynchronization of ovulation and TAI. Conversely, the greater percentage of cows without a CL at NPD in the NoG25 treatment would lead to more cows needing the Ovsynch protocol with P4 supplementation. For example, $13 \%$ of the cows in NoG25 and 9\% of the cows in the G25 treatment needed the Ovsynch protocol with $\mathrm{P} 4$ supplementation in our experiment. This protocol is more expensive and delays re-insemination by a week. The greater proportion of cows without a CL at NPD in the NoG25 group was also responsible for the similar interbreeding interval observed (i.e., delayed re-insemination of cows with NoCL offset the benefit of more inseminations at detected estrus in the NoG25 treatment). Although the benefits and drawbacks of each program for nonpregnant cows may offset each other, another benefit of the NoG25 treatment would be not giving GnRH to pregnant cows $25 \pm 3 \mathrm{~d}$ after AI. Removing this treatment would reduce reproductive program costs and labor because of fewer hormonal treatments while avoiding the unnecessary treatment of pregnant cows. Many factors important to the success of the programs tested in this experiment, such as estrus detection efficiency, response to GnRH, ovarian responses after a previous $\mathrm{AI}$, and P/AI, vary dramatically across farms. There- fore, the choice of management strategy for individual farms could be based on the expected success for each program or the preference to inseminate more cows at detected estrus or TAI (or both).

In support of our hypothesis, $\mathrm{P} / \mathrm{AI}$ for cows with a CL at NPD in the NoG25 treatment was reduced, reflecting the detrimental effect of removing the GnRH treatment $25 \pm 3 \mathrm{~d}$ after AI. Few experiments evaluated the effect of removing the first GnRH of Ovsynch-type resynchronization protocols in lactating dairy cows. For example, Stevenson and Martel (2009) reported no difference in $\mathrm{P} / \mathrm{AI}$ when cows received either saline or GnRH $25 \pm$ 3 d after AI (24.8 vs. $27.7 \%$, respectively) but a $50 \%$ reduction in $\mathrm{P} / \mathrm{AI}$ when the same treatments were compared $32 \pm 3$ d after AI (29.5 vs $19.8 \%$, respectively). Taken together, the results of previous experiments and ours support the notion that the time interval after AI to initiate a shortened protocol (i.e., without the initial GnRH) may be relevant to the fertility of TAI services. Initiating such a protocol at approximately $32 \pm 3 \mathrm{~d}$ after AI seems optimal because of the high proportion of cows that are at a favorable stage of the estrous cycle at this time point.

Interestingly, $\mathrm{P} / \mathrm{AI}$ for cows with a CL in the NoG25 treatment was within the range observed for cows resynchronized with Ovsynch (Fricke et al., 2003; Sterry et al., 2006; Bruno et al., 2014) despite removing the GnRH treatment to initiate a new follicular wave during the protocol. The greater $\mathrm{P} / \mathrm{AI}$ for cows with a CL in the G25 treatment, however, suggests that fertility was suboptimal for cows that did not receive GnRH 25 $\pm 3 \mathrm{~d}$ after AI. This was in spite of the fact that only cows at a favorable stage of the estrous cycle at NPD received the shortened protocol. The most likely explanation for reduced $\mathrm{P} / \mathrm{AI}$ was the smaller proportion of cows that initiated a new follicular wave $7 \mathrm{~d}$ before NPD. Another contributing factor to the reduced P/ AI could have been greater variation for time to initiation of the follicular wave. Indeed, the well-documented benefit of ovulation in response to the first $\mathrm{GnRH}$ of Ovsynch-type protocols on fertility of TAI (Chebel et al., 2003; Bisinotto et al., 2010; Keskin et al., 2010) has been attributed, at least in part, to better synchronization of follicle development (Pursley et al., 1995; Vasconcelos et al., 1999; Wiltbank et al., 2011). Our data for ovarian responses suggest that for most cows the ovulatory follicle in the NoG25 treatment was older. This observation was supported by the differences in pattern of ovulation before NPD, follicle size at NPD, and the longer period of dominance of the ovulatory follicle. This is relevant because it has been suggested that extending the period of dominance of the ovulatory follicle is detrimental to embryo quality due to 
asynchrony between timing of oocyte maturation and ovulation (Revah and Butler, 1996). Extending the period of dominance by $2 \mathrm{~d}$, similar to our observations, did not reduce fertilization rate but reduced embryo quality (Cerri et al., 2009). Therefore, we speculate that the longer period of dominance of the ovulatory follicle for cows with a CL in the NoG25 treatment might explain, at least in part, the reduced $\mathrm{P} / \mathrm{AI}$ for these cows. It is also possible that for some cows the opposite problem reduced fertility to TAI. In this case, cows that ovulated very close to the day of NPD could have had an immature follicle at the time of the GnRH before TAI.

Although the variation in timing of initiation of the new follicular wave is the most likely reason for the difference in $\mathrm{P} / \mathrm{AI}$ for cows with a CL, we cannot separate or rule out the potential confounding effect of inseminating more cows at detected estrus in the NoG25 treatment. It is possible that some cows inseminated at detected estrus in NoG25 may have conceived if they received TAI. This is supported by the relatively high $\mathrm{P} / \mathrm{AI}$ for cows inseminated at detected estrus in NoG25 and the similar P/AI for both treatments when combining data for all AI services. On other hand, we explored the potential confounding effect of parity on $\mathrm{P} / \mathrm{AI}$ because more primiparous than multiparous cows were detected in estrus before NPD. However, the proportion of primiparous cows that had a CL at NPD and received TAI was similar for NoG25 and G25 ( 19\%), and thereby the lower P/AI for the NoG25 treatment could not be attributed to the effect of parity.

Customizing synchronization of ovulation protocols to the ovarian status of cows can reduce the interbreeding interval (current experiment), increase AI at detected estrus (Stevenson et al., 2003; Giordano et al., 2015), and optimize P/AI (Sterry et al., 2006; Bisinotto et al., 2015; Giordano et al., 2016). Differential treatment of cows without a CL at NPD in our experiment ensured substantially greater $\mathrm{P} / \mathrm{AI}$ than expected if these cows would have received the shortened protocol. Indeed, P/AI for cows with no CL (39.4\% for both treatments combined) was relatively high and similar to that observed in other experiments (Giordano et al., 2016). These cows did not benefit from a shorter interbreeding interval; however, greater $\mathrm{P} / \mathrm{AI}$ because of the Ovsynch protocol with $\mathrm{P} 4$ supplementation was likely more beneficial than a shorter interbreeding interval. This is because time to pregnancy is extended more if cows receive TAI with a low chance of conception than if they are restarted in a synchronization of ovulation protocol that leads to greater $\mathrm{P} / \mathrm{AI}$.

Adding the second $\mathrm{PGF}_{2 \alpha}$ before TAI to all protocols in our experiment may explain the relatively high
$\mathrm{P} / \mathrm{AI}$ observed for TAI services. This treatment was added because it has been well documented that luteal regression in lactating dairy cows is suboptimal (Brusveen et al., 2009; Martins et al., 2011; Giordano et al., 2012d). Therefore, 2 rather than $1 \mathrm{PGF}_{2 \alpha}$ treatment is more effective to induce complete luteal regression and minimize circulating concentrations of $\mathrm{P} 4$ before TAI (Ribeiro et al., 2012; Carvalho et al., 2015; Wiltbank et al., 2015). Also, extended luteal phases and interovulatory intervals are common in lactating dairy cows because of the incidence of embryonic death around the period of maternal recognition of pregnancy (Wijma et al., 2016). Therefore, we expected and observed (data not shown) that some cows would ovulate less than 7 d before NPD. A second $\mathrm{PGF}_{2 \alpha}$ treatment would be necessary to induce complete luteal regression for these cows with a less mature CL (Henricks et al., 1974; Wiltbank et al., 2015).

\section{CONCLUSIONS}

We conclude that removing the first GnRH treatment of the Resynch-25 protocol with $2 \mathrm{PGF}_{2 \alpha}$ treatments for cows with a CL at NPD, and using a modified Ovsynch protocol with P4 supplementation for cows with no CL at NPD allowed insemination of a greater proportion of cows at a detected estrus but did not affect the overall proportion of pregnant cows. Nevertheless, P/AI for cows with a CL at NPD was reduced in cows that did not receive GnRH $25 \pm 3$ d after AI. The most likely reason for reduced $\mathrm{P} / \mathrm{AI}$ was more variation in timing of initiation of the follicular wave that gave rise to the ovulatory follicle. Nevertheless, because of differences in detection of estrus before NPD we could not separate or rule out the potential effect of having differences in the population of cows that received TAI. Additional research is needed to determine the effect of the treatments tested in this experiment on time to pregnancy during lactation and profitability of dairy herds.

\section{ACKNOWLEDGMENTS}

We thank personnel from the Dairy Unit of the Cornell University Ruminant Center for helping with cow management during the experiment. This material is based upon work supported by the National Institute of Food and Agriculture, US Department of Agriculture, Hatch under 1007421, and Multistate 100572 to J.O.G. Any opinions, findings, conclusions, or recommendations expressed in this publication are those of the authors and do not necessarily reflect the view of the National Institute of Food and Agriculture (NIFA) or the United States Department of Agriculture (USDA). 


\section{REFERENCES}

Abramson, J. H. 2011. WINPEPI updated: Computer programs for epidemiologists, and their teaching potential. Epidemiol. Perspect. Innov. 8:1.

Berndtson, A. K., S. Vincent, and J. Fortune. 1995. Low and high concentrations of gonadotropins differentially regulate hormone production by theca interna and granulosa cells from bovine preovulatory follicles. Biol. Reprod. 52:1334-1342.

Bisinotto, R. S., R. Chebel, and J. Santos. 2010. Follicular wave of the ovulatory follicle and not cyclic status influences fertility of dairy cows. J. Dairy Sci. 93:3578-3587.

Bisinotto, R. S., I. Lean, W. Thatcher, and J. Santos. 2015. Metaanalysis of progesterone supplementation during timed artificial insemination programs in dairy cows. J. Dairy Sci. 98:2472-2487.

Bruno, R. G., J. Moraes, J. Hernández-Rivera, K. Lager, P. Silva, A. Scanavez, L. Mendonça, R. Chebel, and T. Bilby. 2014. Effect of an Ovsynch56 protocol initiated at different intervals after insemination with or without a presynchronizing injection of gonadotropin-releasing hormone on fertility in lactating dairy cows. J. Dairy Sci. 97:185-194.

Brusveen, D. J., A. Souza, and M. Wiltbank. 2009. Effects of additional prostaglandin F2 $\alpha$ and estradiol-17 $\beta$ during Ovsynch in lactating dairy cows. J. Dairy Sci. 92:1412-1422.

Caraviello, D. Z., K. Weigel, P. Fricke, M. Wiltbank, M. Florent, N. Cook, K. Nordlund, N. Zwald, and C. Rawson. 2006. Survey of management practices on reproductive performance of dairy cattle on large US commercial farms. J. Dairy Sci. 89:4723-4735.

Carvalho, P. D., M. Fuenzalida, A. Ricci, A. Souza, R. Barletta, M. Wiltbank, and P. Fricke. 2015. Modifications to Ovsynch improve fertility during resynchronization: Evaluation of presynchronization with gonadotropin-releasing hormone $6 \mathrm{~d}$ before initiation of Ovsynch and addition of a second prostaglandin F2 $\alpha$ treatment. J. Dairy Sci. 98:8741-8752.

Cerri, R. L., H. M. Rutigliano, R. C. Chebel, and J. E. Santos. 2009 Period of dominance of the ovulatory follicle influences embryo quality in lactating dairy cows. Reproduction 137:813-823.

Chebel, R. C., J. E. Santos, R. L. Cerri, K. N. Galvão, S. O. Juchem, and W. W. Thatcher. 2003. Effect of resynchronization with $\mathrm{GnRH}$ on day 21 after artificial insemination on pregnancy rate and pregnancy loss in lactating dairy cows. Theriogenology 60:1389-1399.

Ferguson, J. D., and A. Skidmore. 2013. Reproductive performance in a select sample of dairy herds. J. Dairy Sci. 96:1269-1289.

Fricke, P. M., D. Caraviello, K. Weigel, and M. Welle. 2003. Fertility of dairy cows after resynchronization of ovulation at three intervals following first timed insemination. J. Dairy Sci. 86:3941-3950.

Galvão, K. N., P. Federico, A. De Vries, and G. M. Schuenemann 2013. Economic comparison of reproductive programs for dairy herds using estrus detection, timed artificial insemination, or a combination. J. Dairy Sci. 96:2681-2693.

Galvão, K. N., J. Santos, R. Cerri, R. Chebel, H. Rutigliano, R. Bruno, and R. Bicalho. 2007. Evaluation of methods of resynchronization for insemination in cows of unknown pregnancy status. J. Dairy Sci. 90:4240-4252.

Giordano, J. O., P. Fricke, and V. Cabrera. 2013. Economics of resynchronization strategies including chemical tests to identify nonpregnant cows. J. Dairy Sci. 96:949-961.

Giordano, J. O., P. Fricke, J. Guenther, G. Lopes, M. Herlihy, A. Nascimento, and M. Wiltbank. 2012a. Effect of progesterone on magnitude of the luteinizing hormone surge induced by two different doses of gonadotropin-releasing hormone in lactating dairy cows. J. Dairy Sci. 95:3781-3793.

Giordano, J. O., A. Kalantari, P. Fricke, M. Wiltbank, and V. Cabrera. 2012b. A daily herd Markov-chain model to study the reproductive and economic impact of reproductive programs combining timed artificial insemination and estrus detection. J. Dairy Sci. 95:5442-5460.

Giordano, J. O., M. Stangaferro, R. Wijma, W. Chandler, and R. Watters. 2015. Reproductive performance of dairy cows managed with a program aimed at increasing insemination of cows in estrus based on increased physical activity and fertility of timed artificial inseminations. J. Dairy Sci. 98:2488-2501.

Giordano, J. O., M. Thomas, G. Catucuamba, M. Curler, M. Masello, M. Stangaferro, and R. Wijma. 2016. Reproductive management strategies to improve the fertility of cows with a suboptimal response to resynchronization of ovulation. J. Dairy Sci. 99:29672978.

Giordano, J. O., M. Wiltbank, J. Guenther, M. Ares, G. Lopes, M. Herlihy, and P. Fricke. 2012c. Effect of presynchronization with human chorionic gonadotropin or gonadotropin-releasing hormone 7 days before resynchronization of ovulation on fertility in lactating dairy cows. J. Dairy Sci. 95:5612-5625.

Giordano, J. O., M. Wiltbank, J. Guenther, R. Pawlisch, S. Bas, A. Cunha, and P. Fricke. 2012d. Increased fertility in lactating dairy cows resynchronized with Double-Ovsynch compared with Ovsynch initiated $32 \mathrm{~d}$ after timed artificial insemination. J. Dairy Sci. 95:639-653.

Henricks, D. M., J. Long, J. Hill, and J. Dickey. 1974. The effect of prostaglandin F2 $\alpha$ during various stages of the oestrous cycle of beef heifers. J. Reprod. Fertil. 41:113-120.

Jo, M., and J. Fortune. 2003. Changes in oxytocin receptor in bovine preovulatory follicles between the gonadotropin surge and ovulation. Mol. Cell. Endocrinol. 200:31-43.

Keskin, A., G. Yilmazbas-Mecitoglu, A. Gumen, E. Karakaya, R. Darici, and H. Okut. 2010. Effect of hCG vs. GnRH at the beginning of the Ovsynch on first ovulation and conception rates in cyclic lactating dairy cows. Theriogenology 74:602-607.

Komar, C. M., A. K. Berndtson, A. C. Evans, and J. E. Fortune. 2001. Decline in circulating estradiol during the periovulatory period is correlated with decreases in estradiol and androgen, and in messenger RNA for p450 aromatase and p450 17alpha-hydroxylase, in bovine preovulatory follicles. Biol. Reprod. 64:1797-1805.

Lima, F. S., E. Ribeiro, R. Bisinotto, L. Greco, N. Martinez, M. Amstalden, W. Thatcher, and J. Santos. 2013. Hormonal manipulations in the 5-day timed artificial insemination protocol to optimize estrous cycle synchrony and fertility in dairy heifers. J. Dairy Sci. 96:7054-7065.

Lopes, G., J. Giordano, A. Valenza, M. Herlihy, J. Guenther, M. Wiltbank, and P. Fricke. 2013. Effect of timing of initiation of resynchronization and presynchronization with gonadotropin-releasing hormone on fertility of resynchronized inseminations in lactating dairy cows. J. Dairy Sci. 96:3788-3798.

Martins, J. P., R. Policelli, L. Neuder, W. Raphael, and J. Pursley 2011. Effects of cloprostenol sodium at final prostaglandin F 20 of Ovsynch on complete luteolysis and pregnancy per artificial insemination in lactating dairy cows. J. Dairy Sci. 94:2815-2824.

Mendonça, L. G., S. T. Dewey, G. Lopes, F. A. Rivera, F. S. Guagnini, J. P. Fetrow, T. R. Bilby, and R. C. Chebel. 2012. Effects of resynchronization strategies for lactating Holstein cows on pattern of reinsemination, fertility, and economic outcome. Theriogenology $77: 1151-1158$

Moreira, F., C. Orlandi, C. Risco, R. Mattos, F. Lopes, and W. Thatcher. 2001. Effects of presynchronization and bovine somatotropin on pregnancy rates to a timed artificial insemination protocol in lactating dairy cows. J. Dairy Sci. 84:1646-1659.

Pursley, J. R., M. Mee, and M. Wiltbank. 1995. Synchronization of ovulation in dairy cows using PGF $2 \alpha$ and GnRH. Theriogenology 44:915-923.

Revah, I., and W. Butler. 1996. Prolonged dominance of follicles and reduced viability of bovine oocytes. J. Reprod. Fertil. 106:39-47.

Ribeiro, E. S., R. Bisinotto, M. Favoreto, L. Martins, R. Cerri, F Silvestre, L. Greco, W. Thatcher, and J. Santos. 2012. Fertility in dairy cows following presynchronization and administering twice the luteolytic dose of prostaglandin F $2 \alpha$ as one or two injections in the 5-day timed artificial insemination protocol. Theriogenology $78: 273-284$

Rutigliano, H. M., F. Lima, R. Cerri, L. Greco, J. Vilela, V. Magalhães, F. Silvestre, W. Thatcher, and J. Santos. 2008. Effects of method of presynchronization and source of selenium on uterine health and reproduction in dairy cows. J. Dairy Sci. 91:3323-3336. 
Scott, B. D. 2016. Incorporation of dairy farm survey data and epidemiological patterns for agent-based simulation modeling of dairy herd dynamics. MS Thesis. Department of Animal Science, Cornell Univ., Ithaca, NY.

Sterry, R. A., M. Welle, and P. Fricke. 2006. Effect of interval from timed artificial insemination to initiation of resynchronization of ovulation on fertility of lactating dairy cows. J. Dairy Sci. 89:20992109.

Stevenson, J., and C. Martel. 2009. Resynchronized ovulation in lactating dairy cattle of unknown pregnancy: Occurrence and timing of gonadotropin-releasing hormone. Prof. Anim. Sci. 25:605-609.

Stevenson, J. S., J. A. Cartmill, B. A. Hensley, and S. Z. El-Zarkouny. 2003. Conception rates of dairy cows following early not-pregnant diagnosis by ultrasonography and subsequent treatments with shortened Ovsynch protocol. Theriogenology 60:475-483.

Stevenson, J. S., and S. L. Pulley. 2016. Feedback effects of estradiol and progesterone on ovulation and fertility of dairy cows after gonadotropin-releasing hormone-induced release of luteinizing hormone. J. Dairy Sci. 99:3003-3015.

Vasconcelos, J. L., R. Silcox, G. Rosa, J. Pursley, and M. Wiltbank. 1999. Synchronization rate, size of the ovulatory follicle, and preg- nancy rate after synchronization of ovulation beginning on different days of the estrous cycle in lactating dairy cows. Theriogenology 52:1067-1078.

Wijma, R., M. Stangaferro, and J. Giordano. 2015. Characterization of ovarian function in nonpregnant previously inseminated lactating dairy cows. J. Dairy Sci. 98(Suppl. 2):96. (Abstr.)

Wijma, R., M. L. Stangaferro, M. M. Kamat, S. Vasudevan, T. L. Ott, and J. O. Giordano. 2016. Embryo mortality around the period of maintenance of the corpus luteum causes alterations to the ovarian function of lactating dairy cows. Biol. Reprod. 95:112.

Wiltbank, M. C., G. M. Baez, F. Cochrane, R. V. Barletta, C. R. Trayford, and R. T. Joseph. 2015. Effect of a second treatment with prostaglandin $\mathrm{F}_{2 \alpha}$ during the Ovsynch protocol on luteolysis and pregnancy in dairy cows. J. Dairy Sci. 98:8644-8654.

Wiltbank, M. C., R. Sartori, M. Herlihy, J. L. M. Vasconcelos, A. Nascimento, A. Souza, H. Ayres, A. Cunha, A. Keskin, and J. Guenther. 2011. Managing the dominant follicle in lactating dairy cows. Theriogenology 76:1568-1582. 